\section{マグネシウム合金への耐食性アルミニウム めっきプロセスに関する考察}

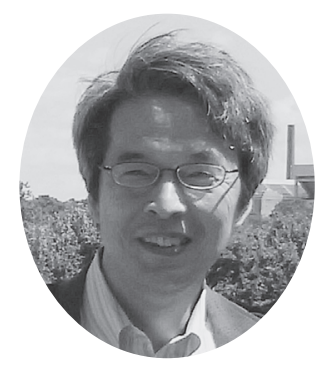

安住 和久* 上田 幹人*.于 航*

Journal of The Japan Institute of Light Metals, Vol. 64, No. 1 (2014), 15-20 (C) 2014 The Japan Institute of Light Metals

\title{
Prospect of corrosion resistive aluminum plating process on magnesium alloys
}

\author{
Kazuhisa AZUMI*, Mikito UEDA* and Yu FANG*
}

Keywords: zincating, ionic liquid, molten salt, adhesivity

\section{1.はじめに}

マグネシウム $(\mathrm{Mg})$ は軽量で比強度が高く, 資源量も豊 富でリサイクル性に優れ, 毒性がなく生体親和性も良好なこ とから，国家戦略的な金属材料として考えられており，輸送 機関や生体材料等への広範な利用拡大が期待されている。そ の一方で，可燃性，プレス性などに難があるほか，耐食性が 著しく劣るため, 実際の利用は携帯電話やノートパソコンの フレーム等の室内用途に限られている。このため, $\mathrm{Mg}$ 合金 に実用的な耐食性を付与するための各種の手法，例えば合金 成分の調整, 熱酸化やアノード酸化による酸化物皮膜形成, シリケート膜や化成膜による被覆, 湿式 (物理) めっきおよ び乾式 (化学) めっきなどが研究開発されている。 Mg 合金

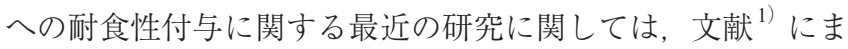
とめられている。耐食性めっきに関しては, 欠陉がなく下地 との密着性が良好なめっき膜の形成が他の金属よりも重要で ある。 $\mathrm{Mg}$ は酸化還元電位が $-2.366 \mathrm{~V}$ と低く, $\mathrm{Ni}$ な゙の耐食 性めっき膜はこれより貴な電位であるため, めっき膜にピン ホールや欠損部が存在すると, 侵入した水分が $\mathrm{Mg}$ 下地と広 い面積のめっき膜をカップルさせて深刻なガルバニック腐食 を進行させる。まためっき膜の密着強度が低いと, 剥離等に よりめっき膜に亀裂などのダメージを与え, やはり腐食起点 となる。しかし Mg 合金の場合, 高い密着強度を得るのが難 しいようである。一般に湿式めっきは多くのプロセスを経る が，浴の組成や $\mathrm{pH}$ によっては Mg 合金が腐食して溶解反応が 継続したり，基板表面に腐食生成物の沈殿を生じることによ り,コーティング層との緻密な結合が妨げられるためである。 Paurbaix ダイアグラム ${ }^{2)}$ によれば, $\mathrm{Mg}$ は $\mathrm{pH} 11.5$ 以下で腐食 を受けるため, これ以下の $\mathrm{pH}$ の処理浴では $\mathrm{Mg}$ 合金下地の腐 食反応を考慮しなければならない3)。またこれ以上の $\mathrm{pH}$ 。゙は
$\mathrm{Mg}$ は不働態化するが, Mgは「Passivation 金属」であるため 表面に水酸化物等の厚い皮膜を生成し, 表面の電導性が低下 したり，析出物との強固な結合を阻害する。また置換反応の ような $\mathrm{Mg}$ の溶解を必要とする反応は進行しない。プロセス の進行に伴って試料表面近傍の $\mathrm{pH}$ が変化する場合は, $\mathrm{Mg}$ 表 面は腐食状態と不㗢態の間を遷移することになり，意図せぬ 溶解や水酸化物の沈殿等が発生する。これは電析初期などで 下地表面が次第に析出物で覆われて閉鎖空間になってゆく過 程で起こりえる。したがってめっきの各プロセスにおける腐 食状況を考慮し，これを抑制したり，場合によっては加速さ せることで，望ましい析出層あるいは界面構造を得るように プロセスを設計する必要がある。図1に，筆者らがこれまで 行ってきた $\mathrm{Mg}$ 合金への耐食性コーティングのプロセスを示 す。本解説では, 上述のような観点から, 主に耐食性 $\mathrm{A} 1$ めつ きを得るための各プロセスの考え方に関して紹介する。

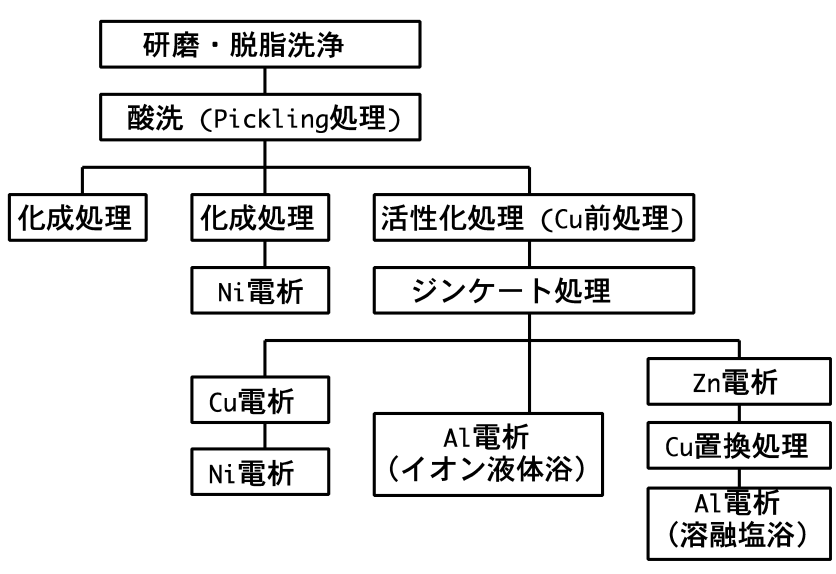

図1 マグネシウム合金への湿式コーティングプロセス の例

\footnotetext{
*北海道大学大学院工学研究院物質化学部門（ $\bar{T} 060-8628$ 北海道札幌市北区北 13 条西 8 丁目)。Laboratry of Electronic Materials Chemistry, Faculty of Engineering Materials Chemistry Functional Materials Chemistry, Hokkaido University (Kita 13, Nishi 8, Kita-ku, Sapporo-shi, Hokkaido 0608628). E-mail: azumi@eng.hokudai.ac.jp
}

受付日：平成25年7月29日＼cjkstart受理日：平成25年 8月22日 
(a) Galvanic type dissolution

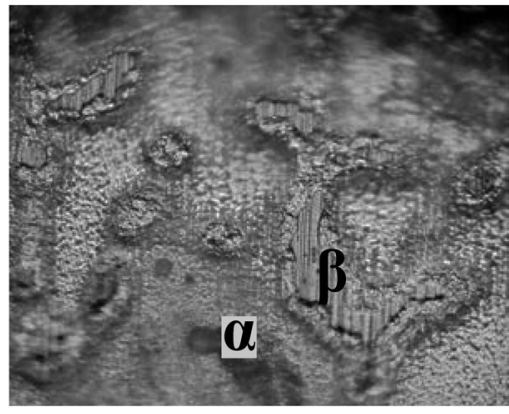

in 0.5 mass $\% \mathrm{HCl}$

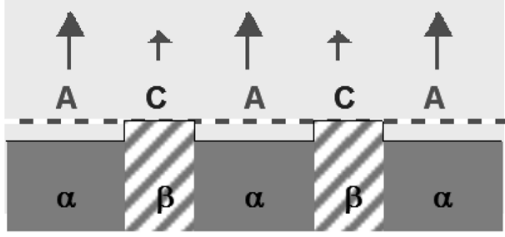

(b) Pitting type dissolution

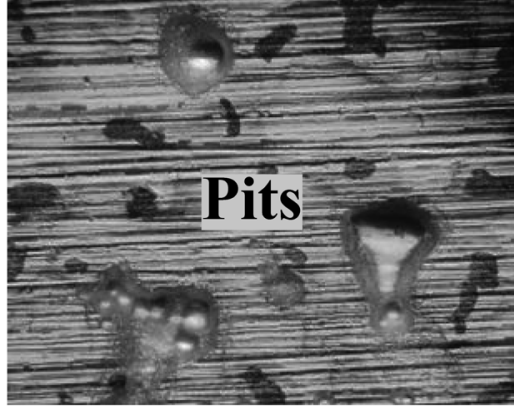

in $0.5 \operatorname{mass} \% \mathrm{HF}$

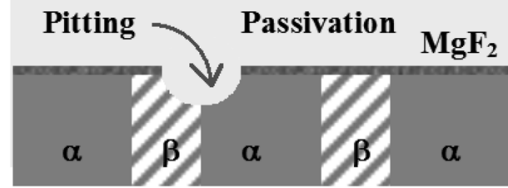

(c) Uniform dissolution

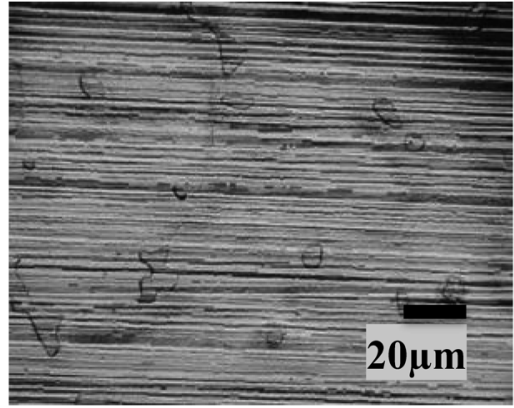

in 0.25 mass \% $\mathrm{HCl}+0.25$ mass \% $\mathrm{HF}$ (Optimized composition)

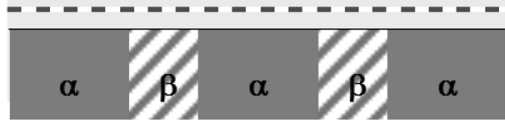

図 230 秒間ピックリング処理した後のAZ91D合金表面の顕微鏡像。処理浴はそれぞれ (a) 0.5 mass \% HCl, (b) 0.5 mass\% $\mathrm{HF}$, (c) 0.25 mass $\% \mathrm{HCl}+0.25$ mass $\% \mathrm{HF}$

\section{2. 具体的プロセスの例}

\section{1. 酸洗処理}

めっき処理の実プロセスにおいて，試料は機械加工・研磨 されたあと，アルカリ浴洗で脱脂され，表面酸化物等を溶解 除去するために各種の酸水溶液により酸洗処理される。基板 の表面形態は後続の各種処理の均一性や最終のめっき形態に 影響するため, 酸洗処理において溶解反応が均一に進行する ことが重要である。特に，代表的な実用合金であるAZ91Dの 場合, $\mathrm{Mg}$ リッチな $\alpha$ 相と $\mathrm{Al}$ 濃度の高い $\beta$ 相が酸溶液によって 異なる溶解特性を示す（図 2)。例えば $0.5 \% \mathrm{HCl}$ 塩酸水溶液 中では $\alpha$ 相と $\beta$ 相がカップリングして $\alpha$ 相が優先溶解し, 一方, $0.5 \%$ ふっ酸水溶液中では不溶性 $\mathrm{MgF}_{2}$ 層で被覆された合金表 面の一部が活性溶解して溶解痕を形成し，いずれも不均一な 溶解形態となる。そこで塩酸とふっ酸を適切な濃度 $(0.25 \%$ $\mathrm{HCl}+0.25 \% \mathrm{HF})$ で混合し，それぞれの溶解機構を抑制するこ とで，酸溶解による表面形態を均一化することができた ${ }^{4)}$ 。

\section{2. 活性化処理およびジンケート処理}

活性化処理では，基板表面に後続の反応に対する活性を付 与する。 $\mathrm{Mg}$ は水溶液環境で容易に酸化されることから, 酸 化物や水酸化物等からなる表面層を酸洗処理でいったん除去 しても直ちに再酸化されて比較的厚い皮膜で再び被覆される と考えられる。このような表面層は電子移動反応に対する障 害となるため, $\mathrm{Mg}$ 合金上に直接めっき膜を電析すると，析 出形態が不均一で密着強度が非常に低い電析膜しか得られな い。このため, めっき過程において $\mathrm{Mg}$ 合金表面を溶解反応 から保護するとともに，電析反応に対する活性を与えるため に，ジンケート処理によるZn中間層の生成が用いられる ${ }^{1)} 。$ ジンケート処理では, $\mathrm{Zn}^{2+}$ イオンを含むジンケート溶液に $\mathrm{Al}$ や $\mathrm{Mg}$ などの卑な金属基板を浸漬し，基板表面の溶解反応 と同時に Zn を置換析出させることで基板表面を Zn 層で被覆 する。ただし，Znの析出密度は基板の組成や表面状態に極 めて敏感である。特にAZ91Dの場合は $\alpha$ 相と $\beta$ 相が $Z n$ 置換析 出反応に対して電気化学的活性の異なる 2 種類の電極面とし
て作用するため, ジンケート処理において Zn は $\alpha$ 相表面に優 先析出する一方， $\beta$ 相にはあまり析出せず不均一な置換面と なる。このような不均一析出に関しては, 超音波照射などで 改善することもできるが， $\beta$ 相表面における密着強度はあま り改善されない ${ }^{5)}$ 。

我々は以前 $\mathrm{Al}$ へジンケート処理の前工程として, 微量 の $\mathrm{Cu}^{2+}$ イオンを含む活性化溶液に $\mathrm{Al}$ 基板を浸漬し, $\mathrm{Al}$ 表面 に $\mathrm{Cu}$ 微粒子を高密度で置換析出させる $\mathrm{Cu}$ 前処理に関して報 告した ${ }^{6)}$ 。この処理では, $\mathrm{Cu}$ と $\mathrm{Al}$ との大きな酸化還元電位 差により $\mathrm{Al}$ 基板表面の組成や形状のわずかな違いにかかわ らず $\mathrm{Cu}$ が析出し，また $\mathrm{Cu}^{2+}$ イオン濃度が極めて低いために 個々の析出 $\mathrm{Cu}$ 微粒子はあまり成長しない。このため $\mathrm{Cu}$ 微粒 子はSEMによる表面観察等では確認できないが, 電極全体 としての活性（浸漬電位）を大きく変える。また $\mathrm{Cu}$ の析出 反応は下地溶解と同時に進行するので, $\mathrm{Cu}$ 微粒子は下地金 属に金属結合していると考えられる。Cu微粒子は電導性が 高いために放電反応に対して効率的な活性点を与えるため, 後続のジンケート処理において Zn 置換析出核として作用し て $\mathrm{Al}$ 表面への $\mathrm{Zn}$ 核形成密度を飛躍的に高め, 均一かつ高密 度の Zn 置換膜が得られる。また置換反応が迅速に進むため, 表面が Znで被覆されるまでの時間が短くなり, 不必要な下 地の溶解が抑制できる利点もある。

このような手法は, 表面活性の低い $\mathrm{Mg}$ 合金に対しても有 効であると考えられたため, $\mathrm{Cu}$ 前処理を併用したジンケー 卜前処理条件を $\mathrm{Mg}$ 合金に対して調整した ${ }^{7), 8)}$ 。図3に，ジ ンケート処理中のAZ91Dの浸漬電位の経時変化を示す。ジ ンケート処理の際, 浸漬電位は $\mathrm{Mg}$ 溶解反応とともに卑側に シフトし，その後表面がZnで被覆されるにつれて貴側にシ フトする。 $\mathrm{Cu}$ 前処理を施した試料は, 施さない試料よりも 浸漬電位の卑側のピークがわずかに貴であり，また置換反応 時間も短くなっている。すなわち, $\mathrm{Cu}$ 前処理により置換反 応が効率的に短期間で進行したことを示す。図4に, Cu 前 処理を施した試料（図4(a)）と施さない試料（図 4(b)）に 対してジンケート処理を行ったAZ91D表面のSEM像を示 

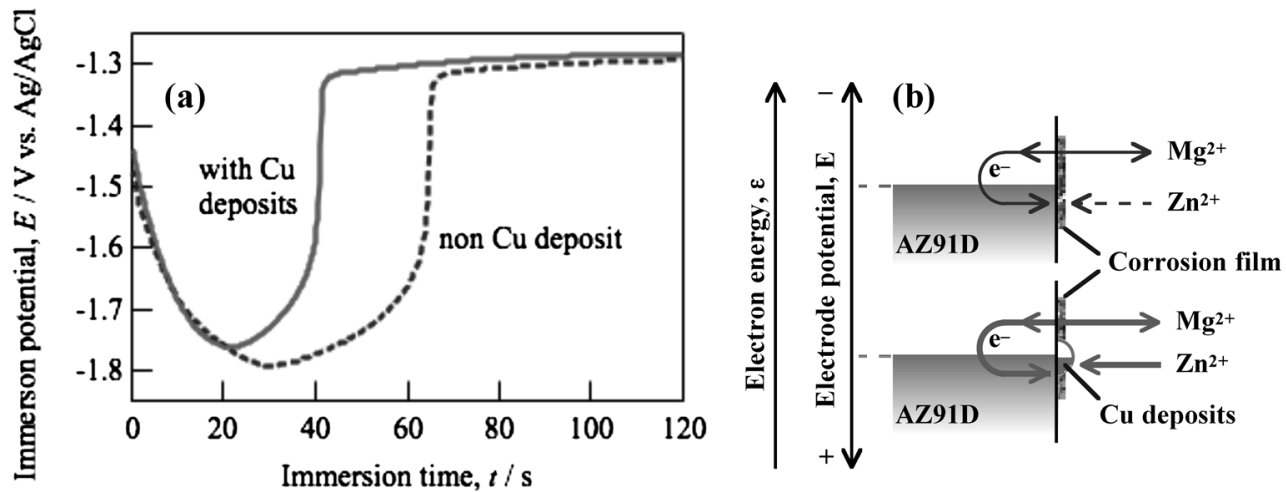

図3（a） Cu 前処理 AZ91D および未処理 AZ91Dをジンケート処理した際の浸漬電位の経時変化，（b） Cu前処理の有無 によるマグネシウム合金の浸漬電位差の成因

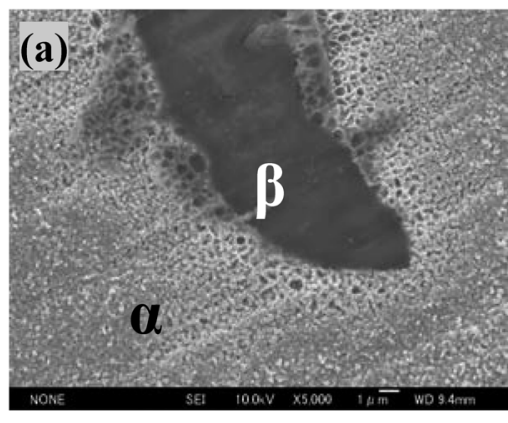

(d)

\section{Preferential dissolution / deposition on $\alpha$-phase surface}

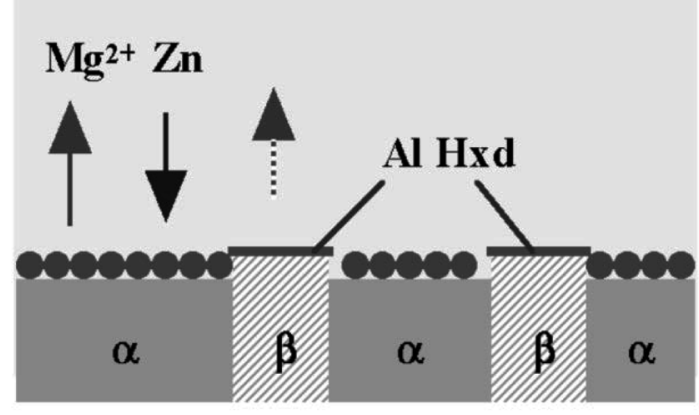

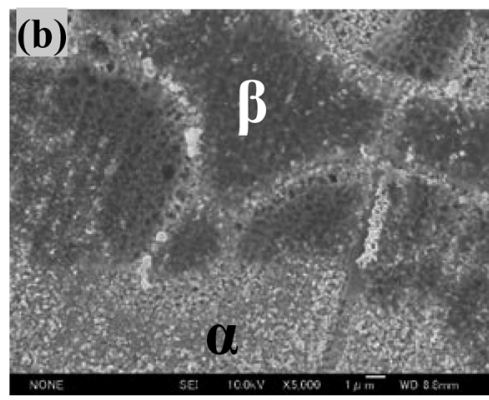
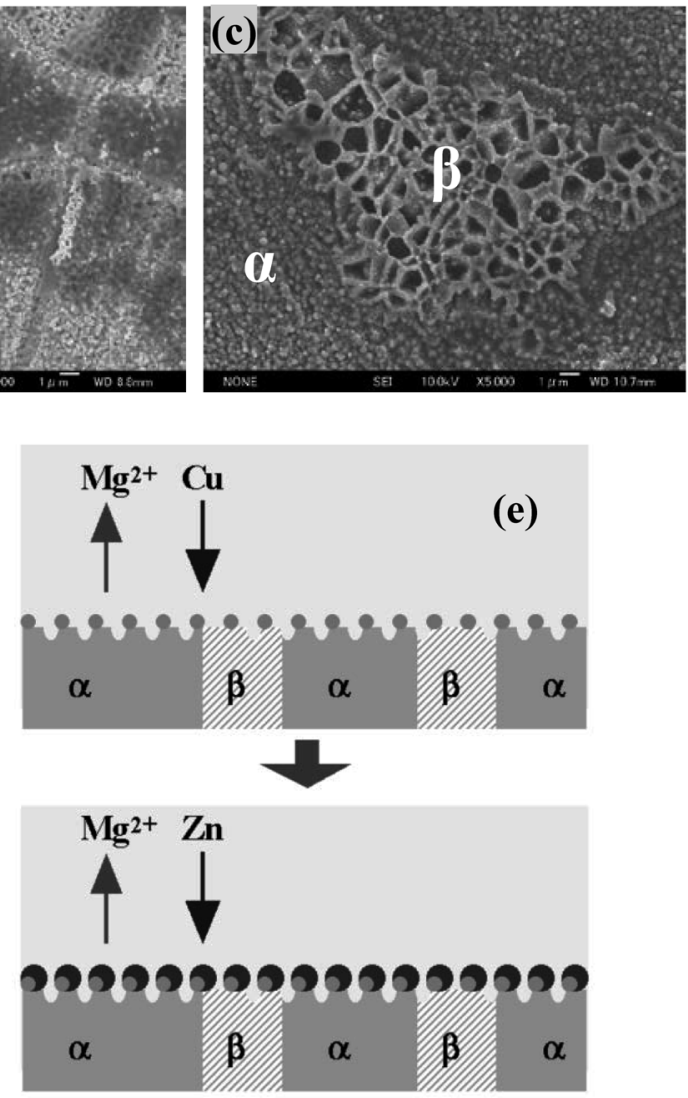

図4 AZ91D合金を超音波照射下で 1000 秒間ジンケート処理した後の表面 SEM 像。（a） Cu 前処理なし試料，（b,c） Cu 前処理試料, (d, e ) 試料 (a) および試料（b）のような析出状態を与える機構の説明図

す。未処理試料では $\alpha$ 相のみにZnが析出しているのに対し, $\mathrm{Cu}$ 微粒子を析出させた AZ91D表面は, $\mathrm{Cu}$ の高い活性によっ て $\alpha$ 相と $\beta$ 相の活性の差異がマスクされ，両相ともに Znが析 出している。またジンケート処理中に超音波照射を行うこ とで $\beta$ 相表面への $\mathrm{Zn}$ 析出がさらに加速されたが，多孔質的な 析出形態となった (図 $4(\mathrm{c}))$ 。同様に, $\mathrm{Al}$ 濃度の低い AZ31 についても $\mathrm{Cu}$ 前処理を施したところ，未処理試料では粒界 において若干の Zn 優先析出が顕在化したのに対して, $\mathrm{Cu}$ 前 処理試料では $\mathrm{Zn}$ 析出の均一性が向上した ${ }^{8)}$ 。以上のように, $\mathrm{Cu}$ 前処理により $\mathrm{Zn}$ 置換膜の密度が向上するとともに, $\mathrm{Cu}$ 微 粒子を介して下地とのより強固な結合が得られるため, 最終 的なめっき膜の密着強度の向上も期待できる。我々はジン
ケート処理AZ91D合金に対して水系めっき浴から $\mathrm{Cu}$ または $\mathrm{Cu} / \mathrm{Ni}{ }^{5), 7), 8)}$, イオン液体浴から $\mathrm{Al}$ を電析させ ${ }^{9)}$, それぞ れ密着強度の高い良好なめっき膜を生成することができた。 なお, $\mathrm{Zn}$ の標準電極電位は比較的卑なため, 電析により単 純浸漬ジンケート置換膜よりも厚い $\mathrm{Zn}$ 中間層を生成するこ とで, ピンホールなどのめっき欠陥部を通してのめっき膜と $\mathrm{Mg}$ 合金下地とのガルバニック腐食が抑制される効果も期待 できる。また, ジンケート処理のほかにも, 下地との密着強 度の高い化成皮膜をめっき膜のプレコートとして用い, めっ き層との密着強度を向上させた例もある ${ }^{10), 11) 。 ~}$

\section{3.イオン液体からのAlめつき}

耐食性めっきとして一般的な $\mathrm{Ni}$ などは比較的貴な金属で 

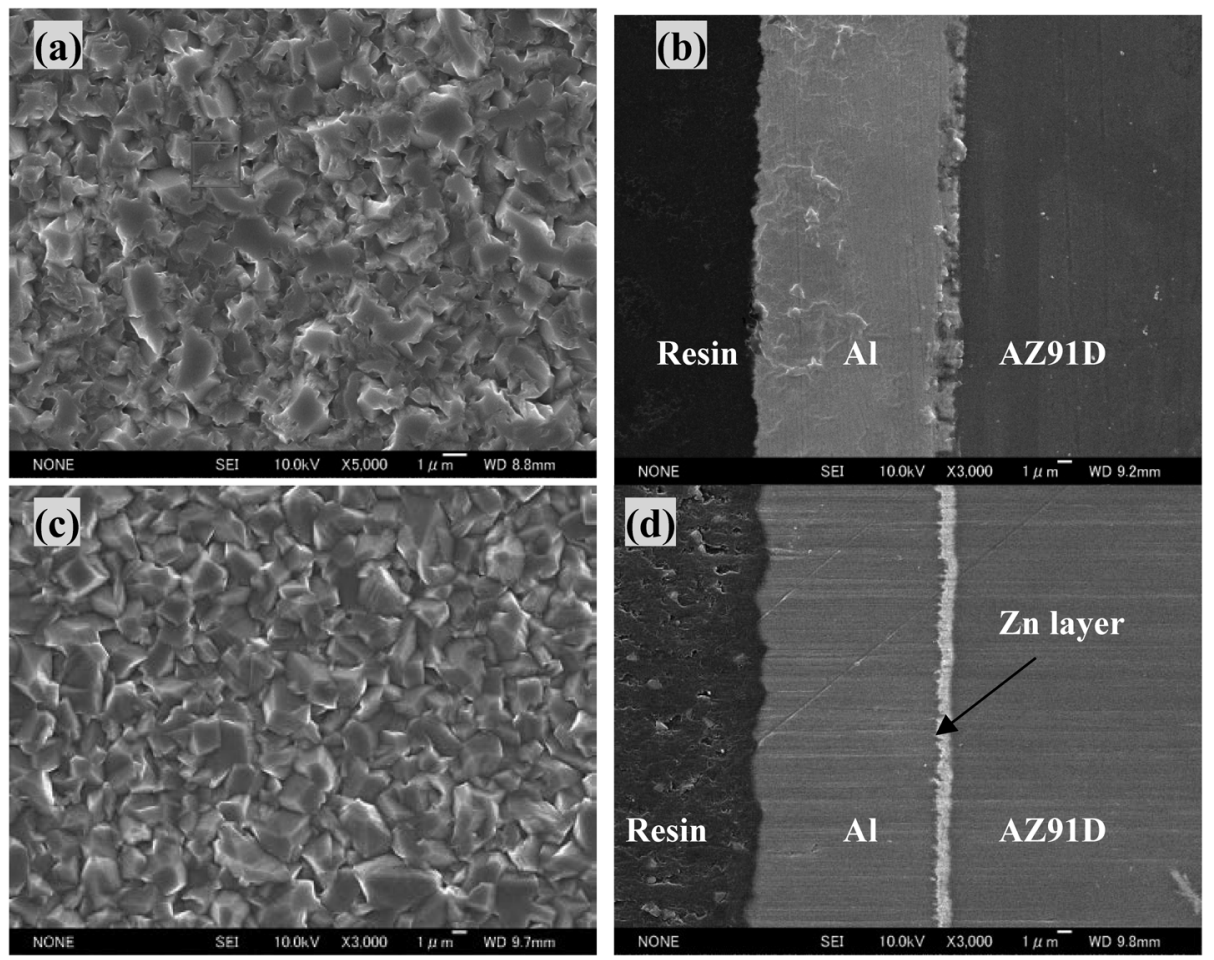

図5 アルミニウム電析したジンケート未処理 $(\mathrm{a}, \mathrm{b})$ およびジンケート処理 $(\mathrm{c}, \mathrm{d})$ AZ91D試料の表面および断面 SEM像。 電析は定電流 $\left(\mathrm{a}, \mathrm{b}: i_{\mathrm{C}}=-8 \mathrm{mAcm} \mathrm{m}^{-2}, 3600 \mathrm{~s}\right)$ またはパルス分極 $\left(\mathrm{c}, \mathrm{d}: i_{\mathrm{C}}=-25 \mathrm{mAcm}^{-2}, i_{\mathrm{A}}=0.5 \mathrm{mAcm}^{-2}, f=2 \mathrm{~Hz}, \mathrm{duty}\right.$ ratio=0.2) で行った

あり，これで $\mathrm{Mg}$ 合金をめっきすると，めっき欠陥部から水 分が侵入することにより卑な $\mathrm{Mg}$ 合金下地と大面積の貴な めっき膜がカップリングし，めっき膜下で激しい異種金属接 触（ガルバニック）腐食を進展させる恐れがある。このため, めっき膜にも $\mathrm{Al}$ や $\mathrm{Ti}$ のような耐食性のある卑な金属を用い ることが望ましい。特に $\mathrm{Al}$ は $\mathrm{Mg}$ 合金の主要な成分であり, またそれ自身が柔軟な機械的性質を持つため，めっき後の 加工プロセスにおいても有利であると思われる。 $\mathrm{Mg}$ 合金に $\mathrm{Al}$ コーティングを施す手段としては，熱拡散接合や湿式電 析法などがあり，前者は比較的単純なプロセスで強固な接合 が得られる反面, 最終製品のような複雑な形状には適用でき ない。一方湿式法はプロセスが複雑であり，また $\mathrm{Al}$ の標準 電極電位が $-1.662 \mathrm{~V}$ で水分解による水素発生反応の電位よ りも卑であるため, 水系めっき浴からは電析できない。この ため, 溶融塩や有機溶媒，イオン液体を用いためっき浴が検 討されている。このうち有機物イオンから構成されるイオン 液体は, 揮発性が極めて低く安定かつ難燃性であり, 金属イ オンをよく溶かし，粘性が小さく，分子構造を変えることで 親疎水性などさまざまな物性を調整できる，などの特徴を有 する。このため, EMIC-AlCl 3 (1-ethyl-3-methylimidazolium chloride-aluminum chloride) などのイオン液体浴を用いて Mg 合金への $\mathrm{Al}$ または $\mathrm{Al}$ 合金めっきが試みられてきた ${ }^{12) \sim 15) 。 ~}$

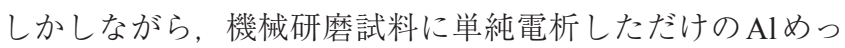
き膜は, 一般に欠陥が多く下地との密着性の低い電析膜しか 得られない。図5 $(a, b)$ に, AZ91Dに対して定電流電解によ り $\mathrm{Al}$ を電析した表面および断面のSEM像を示す。これらの 図より，めっき膜は比較的粒子の大きな析出物からなり，ま ためっき膜/下地界面においてVoidが多いことがわかる。こ のような欠陥のある界面構造となる原因は, 電析初期におい
てAZ91D表面での Al核形成密度が小さいため, それぞれの 核にカソード電流が集中して大きな $\mathrm{Al}$ 粒子がまばらに成長 するためと考えられる。電析の進行に伴いそれぞれの粒子が

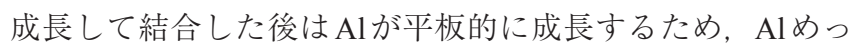
き層の下にはVoidが残される。

こうした欠陥構造を解消するためには, 電析初期の核形成 密度を密なものにするとともに, めっき膜中にもVoidが形 成されないような電析条件を用いる必要がある。このために は, 前述の $\mathrm{Cu}$ 前処理併用ジンケート処理と, パルス電解法 が有効であると思われる(図6 $)^{9)}$, 16)。一般的な定電流カソー ド電析では, 電流密度に対して浴沖合から電極表面への金属 イオン供給が追いつかない場合, 電極表面付近に拡散層が形 成されてイオン濃度が低下するために電析の過電圧が上昇す る。電析物に凹凸がある場合, 凸部が拡散層内の比較的イオ ン濃度が高い領域に侵入するため, 高い過電圧により周囲の イオンを集めながら優先析出が進行する。このため, 凸部は より突出し, 凹部では析出が起こらないため, 空隙率の高い 電析物や針状結晶（デンドライト）が形成される。パルス電 析では間欠的な定電位または定電流カソード分極を行うが, 電解休止時に浴沖合からのイオン拡散により濃度分極が緩和 して拡散勾配が小さくなり, 電解再開時に電極表面に充分な イオンが存在すると電極全面で電析が起こるため, 不均一な 析出が緩和される。電解休止の代わりにわずかなアノード電 流を流すことで (バイポーラパルス電析), 電析の均一化を さらに高めることができる。電析直後の $\mathrm{Al}$ 微結晶表面は構 造緩和が進行していないため表面エネルギーの高い活性な状 態である。アノード溶解により特に活性の高い部位や突出部 が選択溶解して除去されるため, 表面の凹凸およびエネル ギー状態が平準化され, 電析再開時の析出反応がさらに均一 
(a) GP: Galvanostatic Polarization
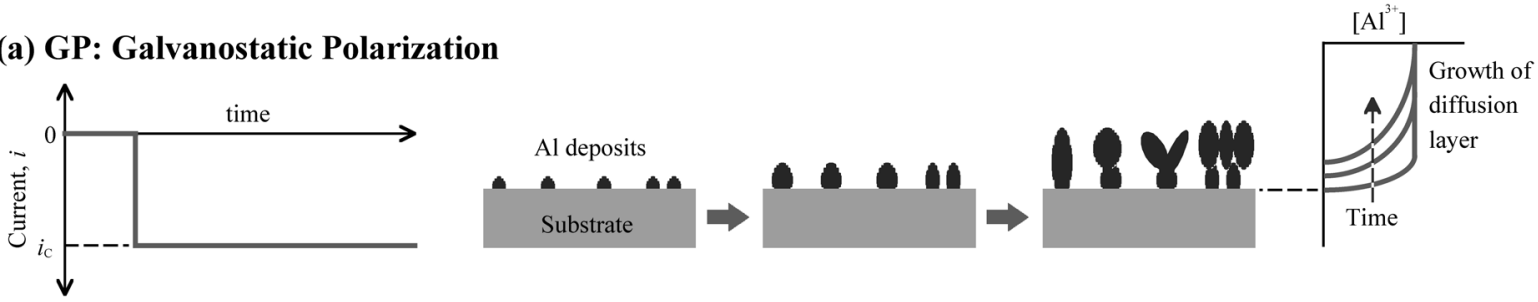

(b) MCP: Monopolar Current Pulse polarization

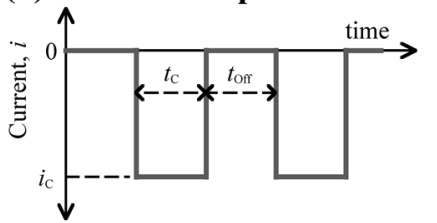

(c)

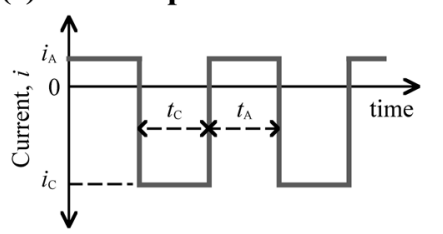

Deposition period

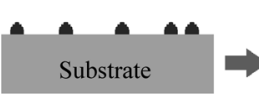

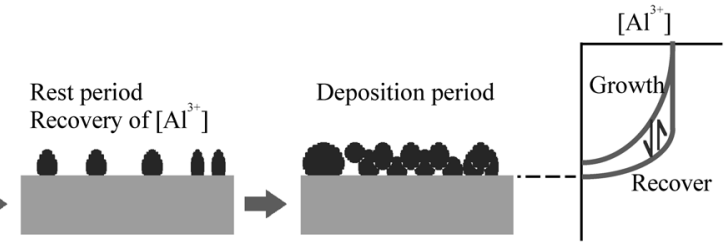

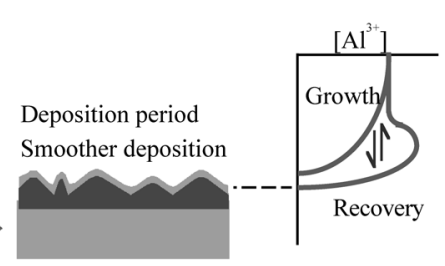

図6 3 種類の分極法における $\mathrm{Al}$ 電析形態と電極近傍 $\mathrm{Al}^{3+}$ イオン拡散層形成状態との関係 ${ }^{1)}$ 。(a) 定電流分極 (GP: Galvanostatic Polarization),（b）単極性パルス分極（MCP: Monopolar Current pulse Polarization), (c) 二極性パル 久分極（BCP: Bipolar Current pulse Polarization）

に進行することが期待される。ただし，実際に均一で久陥の 少ない電析物を得るためには，パルス条件（電流密度, 周波 数、デューティー比など）の最適化が必要であるが，このよ うな条件では時間平均電流密度, すなわちめっき速度が低下 するため，現実のプロセスでは，妥協点を探ることになる。

実際に $\mathrm{Cu}$ 前処理併用ジンケート処理を施したAZ91D に対 してEMIC- $\mathrm{AlCl}_{3}$ イオン液体浴中でバイポーラパルス電析に より $\mathrm{Al}$ 電析した試料の表面抢よび断面 SEM 像を図 $5(\mathrm{c}, \mathrm{d})$ に示す9)。ジンケート未処理試料と比較して, Al電析膜自身 の欠陥と皮膜/下地界面のボイドが抑制されていることがわ かる。この結果, めっき膜の下地に対する密着強度も, 直接 電析膜の 2 3 MPaからジンケート前処理試料の $>11 \mathrm{MPa}$ へ と大きく改善された。

\section{4. 溶融塩浴からのAIめつき}

前節で示したように，非水溶媒浴を用いることで卑な $\mathrm{Al}$ $\mathrm{Mg}$ 合金上に電析できるが, イオン液体試薬は高価であるこ と, めっき浴が酸素や水分の混入に敏感であること, EMIC の場合は腐食性の $\mathrm{HCl}$ ガスが発生する場合もあることなど, 実用に際しての困難がある。これに対して $100 \sim 200^{\circ} \mathrm{C}$ 程度の 中温溶融塩浴では，浴温度が高いために水の混入がなく，反 応速度が大きいために電析速度の向上も期待できる利点があ る。このため, コストの低い $\mathrm{AlCl}_{3}: \mathrm{NaCl}: \mathrm{KCl}$ 三元系溶融塩 浴中での $\mathrm{Al}$ 電析が試みられている。しかしながら溶融塩浴温 度が高いためにめっき中に Mg 合金表面が溶解するなどのダ メージを受けやすく，表面を適切に保護する必要がある。こ のために, 中間層として Zn 電析膜が用いられる ${ }^{17), 18)}$ 。我々 は $\mathrm{AlCl}_{3}: \mathrm{NaCl}: \mathrm{KCl}$ 溶融塩浴中（浴温 $150^{\circ} \mathrm{C}$ ) での $\mathrm{Al}$ 電析に際 して，Mg合金表面を Zn膜で被覆して保護することを試みた。

図7に，各種の処理を施したAZ91D試料を溶融塩浴に浸 漬した際の電位の経時変化を示す。機械研磨したAZ91Dの

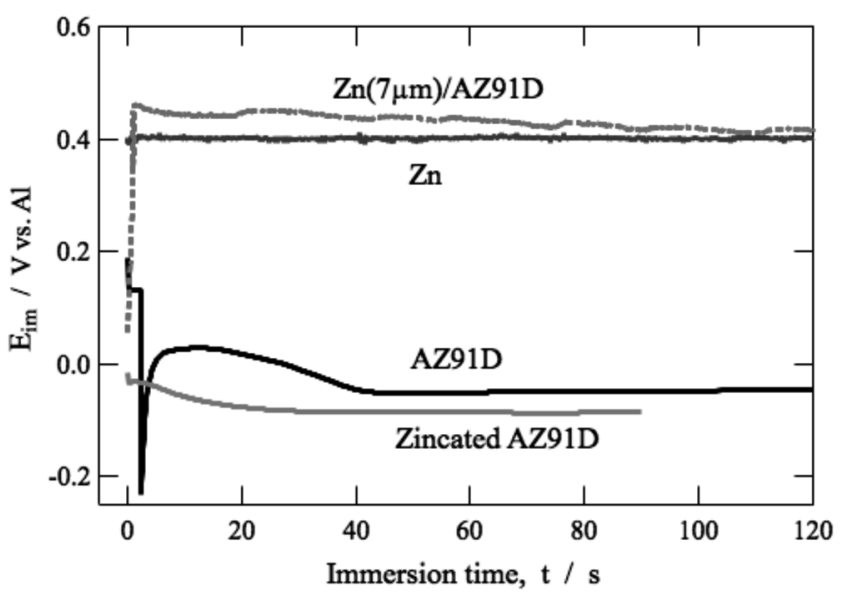

図7 溶融塩浴 $\left(\mathrm{AlCl}_{3}: \mathrm{NaCl}: \mathrm{KCl}, 150^{\circ} \mathrm{C}\right)$ 中における AZ91D およびZn試料の浸漬電位変化

浸漬電位は $\mathrm{Al}$ 参照電極に対して約 $-0.05 \mathrm{~V}$ 付近である。この とき試料表面では $\mathrm{Mg}$ の溶解と $\mathrm{Al}$ の置換析出が進行している が, $\mathrm{Al}$ の析出は不均一であり試料表面のかなりの部分は露出 したままであった。一方, Zn 板の浸漬電位は $+0.4 \mathrm{~V}$ 付近であ り，その表面は溶融塩浴中で劣化しなかった。次に単純浸漬 ジンケート処理によりAZ91D表面に厚さ約 $0.7 \mu \mathrm{m}$ の置換析出 Zn 層を生成してから溶融塩浴に浸漬したところ, 試料の電位 は未処理のAZ91Dとほぼ同じ電位を示したことから, Znに よる試料表面の被覆が完全ではなく, すきまから浸透した溶 融塩浴により下地 $\mathrm{Mg}$ が溶解したものと推定された。このた め, $\mathrm{Mg}$ 合金表面保護のためにはより緻密で厚い Zn 膜が必要 であると考え, ジンケート処理後にカソードパルス電析を行 うことで Zn 層を厚膜化した。厚さ約 $7 \mu \mathrm{m}$ の Zn膜で被覆した AZ91Dの浸漬電位は $\mathrm{Zn}$ 板とほぼ同じ值を $100 \mathrm{~s}$ 以上維持し, 

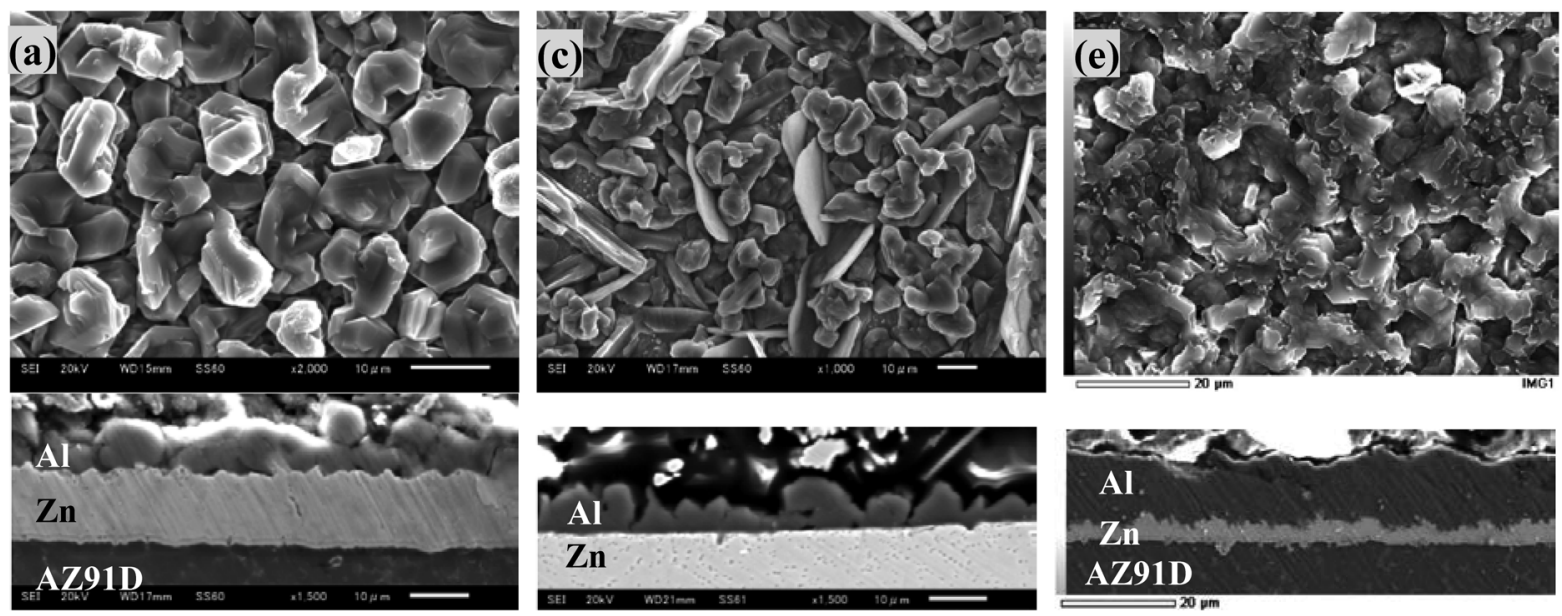

図 8 溶融塩浴 $\left(\mathrm{AlCl}_{3}: \mathrm{NaCl}: \mathrm{KCl}, 150^{\circ} \mathrm{C}\right)$ 中で $\mathrm{Al}$ をパルス電析した（a） $\mathrm{Zn}$ プレコート $\mathrm{AZ91D,}(\mathrm{b} ） \mathrm{Zn}$ 板，（c） $\mathrm{Cu}$ 微 粒子析出により活性化処理したZnプレコートAZ91D各試料の表面および断面 SEM像

$\mathrm{Mg}$ 合金下地を充分に保護できていると言える。なお $7 \mu \mathrm{m}$ と いう厚さは保護目的の中間層としては少々オーバースペック であるが，厚さの最適化等は今後行う予定である。

以上のように厚膜化した Zn 保護層の導入により AZ91D合 金を溶融浴中での溶解反応から保護することができた。前述 の $\mathrm{EMIC}-\mathrm{AlCl}_{3}$ イオン液体浴中では, このような $\mathrm{Zn}$ 置換表面 に対して良好な $\mathrm{Al}$ 電析膜が得られたが，溶融塩浴中で同様 に $\mathrm{Al}$ の電析を試みたところ, 不均一で密着性の極めて低い

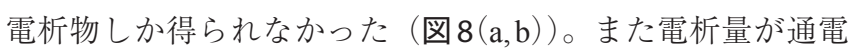
電気量に対して少ないことから, 電析した $\mathrm{Al}$ のちかなり の部分が表面から脱落したと考えられる。この原因は, 溶融 塩浴中における $\mathrm{A} 1$ 析出反応に対する $\mathrm{Zn}$ 表面の低い活性にあ ると推定されたため, $\mathrm{Zn}$ 板に対して $\mathrm{Al}$ 電析を行ったところ, 同様に析出効率の低い皮膜しか得られなかった（図 $8(\mathrm{c}, \mathrm{d}))$ 。 そこで Zn 層の表面の一部を, $\mathrm{Al}$ 電析反応に対する活性の高 い $\mathrm{Cu}$ で置換し, $\mathrm{Al}$ 電析を行ったところ, 良好な $\mathrm{Al}$ 電析膜を 得ることができた（図 $8(\mathrm{e}, \mathrm{f}))$ 。ただし，イオン液体浴中で 得られためっき膜（図 $5(\mathrm{c}, \mathrm{d}))$ と比較して析出の均一性は劣 る。

以上, 溶融塩浴中でのめっきの各プロセスを吟味し, 下地 の腐食反応の抑制と適切な表面活性化処理を考慮すること によって，Al電析めっきを実現することができた。ただし， プロセスが複雑化してしまったこと，電析物の表面形態や中 間層の厚さなどについて改善の余地があることから，これら の簡略化ならびに最適化に関して引続き検討中である。温度 の高い溶融塩浴の場合, 常温の水系浴あるいはイオン液体浴 と比較して，電析物の表面形態が電極上の位置に依存して異 なる傾向を示したが，この原因解明と対策も課題となってい る。また湿式めっき一般に言えることだが，浴成分が湿気を 含む環境中で腐食性を示す場合が多く，下地/めっき界面に これら浴成分が残留した場合，吸湿等による腐食の開始が危 惧される。この点からも，下地/めっき層間の密着性の確保 が重要となる。

\section{3. おわりに}

マグネシウム合金に対する耐食性めっきに関する最近の動 向と, 筆者らの研究成果の一部を紹介した。極めて腐食しや
すいマグネシウム合金に対してめっきを施す場合，めっき処 理中の基板の腐食状況に留意してこれを抑制・制御するこ と, 各処理反応における表面の均一な活性化を充分に行うこ と, これらの方策により欠陥のない界面構造を構築するこ と，などが肝要と考えられる。しかし本報告で示した知見は ほとんどが実験室でのものであり, 実際の工業プロセスでは 浴管理や環境対応, 大面積基板へのめつきの均一性など, 別 の観点での課題が顕在化する。マグネシウム合金は将来性お よび潜在力の高い材料であるが, 諸外国と比較して日本での 研究開発はそれほど活発ではないようである。本報がこの分 野の研究発展にわずかなりとも貢献できれば幸いである。

\section{参 考 文 献}

1) G.-L. Song (Ed.): Corrosion prevention of magnesium alloys, Woodhead Pub., Cambridge, UK, (2013).

2) M. Pourbaix: Atlas of Electrochemical Equilibria in Aqueous Solutions, NACE, Houston, (1974).

3) 安住和久, H. H. Elsentriecy and J. Tang: 表面技術, 62 (2011), 696-701.

4) H. H. Elsentriecy, K. Azumi and H. Konno: Surf. Coat. Tech., 202 (2007), 532-537.

5) J. Tang and K. Azumi: Surf. Coat. Tech., 205 (2011), 3050-3057.

6) K. Azumi, S. Egoshi, S. Kawashima and Y. Koyama: J. Electrochem. Soc., 154 (2007), D220-D226.

7) J. Tang and K. Azumi: Electrochim. Acta, 56 (2011), 8776-8782.

8) J. Tang and K. Azumi: Electrochemical Soc., 158 (2011), D535D540.

9) J. Tang and K. Azumi: Surf. Coat. Tech., 208 (2012), 1-6.

10) H. H. Elsentriecy and K. Azumi: J. Electrochem. Soc., 156 (2009), D70-D77.

11) S. Y. Zhang, Q. Li, B. Chen, S. Q. Xu, J. M. Fan and F. Luo: Mater Corros., 61 (2010), 860-865.

12) J.-K. Chang, S.-Y. Chen, W.-T. Tsai, M.-J. Deng and I.-W. Sun: Electrochem. Commun., 9 (2007), 1602-1606.

13) S.-J. Pan, W.-T. Tsai, J.-K. Chang and I.-W. Sun: Electrochim. Acta, 55 (2010), 2158-2162.

14) M. Ueda, Y. Tabei and T. Ohtsuka: ECS Trans., 33 (2010), 563-570.

15) M. Ueda, S. Hariyama and T. Ohtsuka: J. Solid State Electrochem., 16 (2012), 3423-3427.

16) J. Tang and K. Azumi: Electrochim. Acta, 56 (2011), 1130-1137.

17) J. Zhang, C. Yan and F. Wang: Appl. Surf. Sci., 255 (2009), 49264932.

18) J. Zhang, W. Zhang, C. Yan, K. Du and F. Wang: Electrochim. Acta, 55 (2009), 560-571. 